\title{
On the development of organic chemistry in Ukraine
}

\author{
Dmytro O. Tymoshenko
}

\author{
Department of Combinatorial Chemistry, \\ Albany Molecular Research, Inc., Albany, NY, 12212, U.S.A.
}

Over the years, development of organic chemistry in Ukraine has been connected with its geographical position and natural resources. Being separated into two parts during the $17^{\text {th }}$-early 20th centuries, Ukraine was greatly influenced in its Western part by German and Polish culture. Eastern regions, geographically closer to Russia and extremely rich in coal and other raw materials, were strongly connected with the development of Russian, and later Soviet, science and industry. The Western and Eastern parts of Ukraine were united under Soviet power in 1939. Since then, and through the 1990's, when Ukraine gained independence, organic chemistry, as one of the leading disciplines of science, developed along the same lines in a united Ukraine.

Pharmacists are believed to be one of the first groups of people to deal with organic substances, their simple transformations, and laboratory techniques. The first documented pharmacy in Ukraine was created in Lviv in 1512, and a pharmacist's place was created in Kiev in the $15^{\text {th }}$ century [1]. The first Universities in Ukraine were founded in the 17th century (Kyiv Mogyla Academy, 1659, and Lviv University, 1661). The actual development of chemistry as a science began at the end of the 18th century, when a chemical laboratory was founded at Lviv University (1784, Prof. Schiverek). The first specialized courses in Organic Chemistry were taught starting from the foundation of Kiev University in 1834 (Prof. Zenovich), and at Lviv University for students with their major in Philosophy and Medicine (1851, Prof. Pless); selected topics were also taught at Kharkov University, founded in 1805.

The industrial revolution of the $19^{\text {th }}$ century had a great impact on the development of organic chemistry and its applications in Ukraine, which was at that time divided between the Austrian and Russian Empires. The first Ukrainian sugar factory was built in 1824 in Chernigov province and by the mid 19th century Eastern and Central Ukraine became a largest producer of sugar in Europe. The annual sugar production of 120,000 tons in 1849 almost doubled by 1861 [2]. In 1866 the Ukrainian naturalist and archeologist Alexander Pol', while involved in archaeological research, accidentally opened the Kryvyi Rih (now Dnepropetrovsk district) iron ores. In 1869, John Hughes, a British engineer and entrepreneur, started the first metallurgical plant in the Donetsk region and began the industrial production of coal. At the same time extensive production of oil and gas was started in Western Ukraine in the Boryslav region. This burst in industrial development was a basis for further progress in organic chemistry and chemical technology.

Several prominent Russian chemists joined Kiev and Kharkov Universities in the East, and German and Polish chemists Lviv University in the West. Among them was Prof. Sergei Reformatsky, who founded organozinc chemistry (Reformatsky reaction [3]) and for over 40 
years led the Department of Chemistry at Kyiv University. His book "Organic Chemistry, Beginning Course" was published in 1893 and then re-published 17 times. Synthesis of the imidazole ring by condensing alpha-dicarboxylic compounds with aldehydes and ammonia, was developed in Lviv University in the laboratory of Prof. Bronislaw Radziszewski, and is now known as the Debus-Radziszewski imidazole synthesis [4a,b].

Despite dramatic social changes at the beginning and at the end of the 20th century and the impact of two World Wars, organic chemistry in Ukraine continued to develop. A new generation of distinguished organic chemists arrived, among them Academicians Yavorskii, Shaposhnikov, Kiprianov, Shilov, Kirsanov, Markovskii, Litvinenko, and Babichev. Nowadays, multiple theoretical and practical aspects of organic chemistry are studied in scientific institutions and universities throughout the country.

The institutes of the National Academy of Science (NAS) have gained leading roles and have established well-known scientific schools. Syntheses of cyanine dyes, heterocyclic compounds, organo-fluorine and phosphorous compounds are the major focus at the NAS Institute of Organic Chemistry (Kyiv). Mechanistic and reactivity studies of organic compounds including homogenous and inter-phase catalysis in organic reactions are studied at the Litvinenko Institute of Physical-Organic Chemistry and Coal Chemistry (Donetsk).

Principal research areas at the NAS Institute of Bioorganic Chemistry and Petrochemistry (Kyiv) include the chemistry of biologically active peptides, proteins, nucleic acids and their components, chemical models of biological processes and the study of biological properties of new synthetic regulators for medicine and agriculture. Research activities of the NAS Bogatsky Physical-Chemical Institute (Odessa) are aimed at an investigation of structure-property relationships of supramolecular compounds and the development of direct syntheses of psychotropic, immunotropic, antiviral, antiaggregation substances, metallocomplex catalysts, and sensors. Research related synthetic studies are carried out at the NAS Institute of Macromolecular Chemistry (Kyiv) and NAS Institute of Molecular Biology and Genetics (Kyiv).

The National Taras Schevchenko University (Kyiv), Dnepropetrovsk, Donetsk, Kharkov, Lviv and Odessa National Universities, hold principal positions in synthetic methods, tautomerism, reactivity, luminescent characteristics and physiological activity of $\mathrm{N}-$, S- and Ocontaining heterocyclic compounds including spectroscopic studies of heterocycles and heterocyclic dyes.

Leading technical schools, among them the Polytechnical Universities in Kyiv, Kharkov, Donetsk, the State University "Lvivska Politechnika" and the Ukrainian State University of Chemical Technology (Dnepropetrovsk), conduct research in the areas of general organic, heterocyclic and polymer-supported synthesis and their technical applications.

In this special issue of ARKIVOC dedicated to organic chemistry in Ukraine, contributions from several scientific research groups are presented. It represents scientifically diverse studies from various schools and geographical locations in order to depict modern trends of the field throughout Ukraine. 
1. http://www.irr.lviv.ua/medgeo/histmed_eng.html

2. http://www.sugar-ukr.com/history_e.htm

3. Reformatsky, S. Ber. 1887, 20, 1210.

4. (a) Debus H., Ann. 1858, 107, 204. (b) Radziszewski B. Ber., 1882, 15, 2706. 